
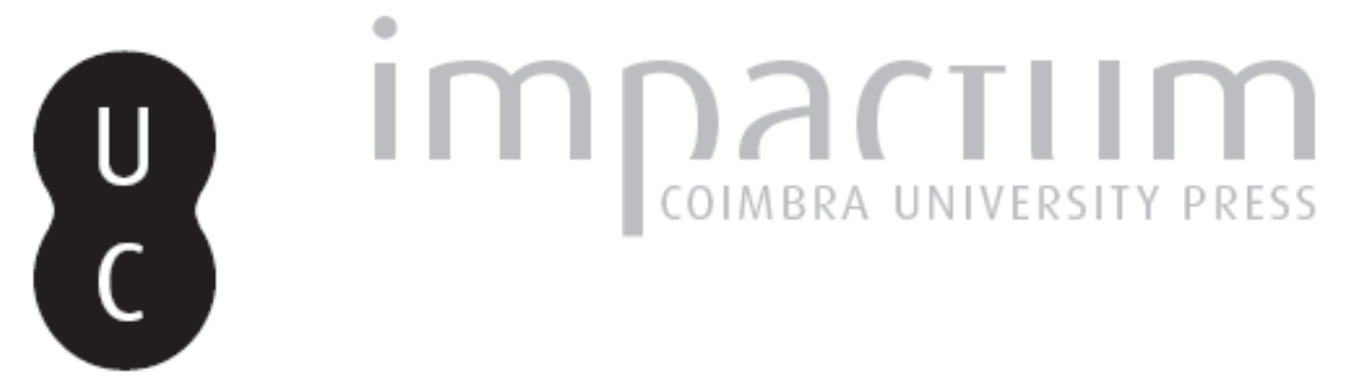

\title{
Evolution, primates and Charles Darwin
}

\section{Autor(es): Casanova, Catarina}

Publicado por: CIAS - Centro de Investigação em Antropologia e Saúde

URL persistente:

URI:http://hdl.handle.net/10316.2/28695

DOI:

DOI:http://dx.doi.org/10.14195/2182-7982_27_12

Accessed : $\quad$ 26-Apr-2023 09:49:57

A navegação consulta e descarregamento dos títulos inseridos nas Bibliotecas Digitais UC Digitalis, UC Pombalina e UC Impactum, pressupõem a aceitação plena e sem reservas dos Termos e Condições de Uso destas Bibliotecas Digitais, disponíveis em https://digitalis.uc.pt/pt-pt/termos.

Conforme exposto nos referidos Termos e Condições de Uso, o descarregamento de títulos de acesso restrito requer uma licença válida de autorização devendo o utilizador aceder ao(s) documento(s) a partir de um endereço de IP da instituição detentora da supramencionada licença.

Ao utilizador é apenas permitido o descarregamento para uso pessoal, pelo que o emprego do(s) título(s) descarregado(s) para outro fim, designadamente comercial, carece de autorização do respetivo autor ou editor da obra.

Na medida em que todas as obras da UC Digitalis se encontram protegidas pelo Código do Direito de Autor e Direitos Conexos e demais legislação aplicável, toda a cópia, parcial ou total, deste documento, nos casos em que é legalmente admitida, deverá conter ou fazer-se acompanhar por este aviso.

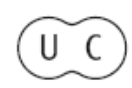




\section{Antropologia Portuguesa}

Volume $26-27 \cdot 2009-2010$

Departamento de Antropologia | Universidade de Coimbra

DARWINISMO:

revisitações, propostas, problemas 


\title{
Evolution, Primates and Charles Darwin
}

\author{
Catarina Casanova \\ CAPP, Instituto Superior de Ciências Sociais e Políticas da Universidade Técnica de Lisboa, Portugal. \\ CBA, Faculdade de Ciências da Universidade de Lisboa, Lisboa, Portugal \\ ccasanova@iscsp.utl.pt
}

\begin{abstract}
While the "Darwin Year 2009" celebrations take place world-wide and answering to the challenge posed by Antropologia Portuguesa, the present work aims to highlight the meticulous observation and innovative thinking by Charles Darwin and simultaneously to describe some of the most significant bench mark discoveries regarding primate evolutionary processes. I start by arguing that prejudices are the main reason behind old and contemporary constraints to evolutionary theory proposed by Darwin. Today, many of Darwin's publications are still nuclear milestones and represent some of the greatest ever contributions to science. Nevertheless, due to prejudice and ignorance, the theory of evolution still struggles to be accepted in certain forums. In the first part of this work I quote Darwin to illustrate his visionary and advanced ideas regarding the origins and evolution of primates (humans included). Although in the Victorian $19^{\text {th }}$ century, Darwin's thoughts about other primates and specially humans can be considered prejudice free. The second part of this works departs into a voyage to the past, millions and millions of years ago, from primate ancestors until the appearance of the first hominines. Such short and resumed voyage is backed up not only by describing evidences coming from the fossil record but also using knowledge coming from Primatology and Ethnology. This work ends with an also resumed description of chimpanzee behaviour, and social organization as a referential model to enlighten the human evolutionary process.
\end{abstract}

Key words Darwin; prejudice; evolution; primates; chimpanzees.

Resumo Em plenas celebrações mundiais do "Ano de Darwin 2009" e respondendo ao desafio colocado pela Antropologia Portuguesa, este trabalho pretende realçar o pensamento inovador de Charles Darwin e, simultaneamente, descrever algumas das mais significativas descobertas do registo fóssil de primatas. Assim, este artigo não é um trabalho clássico de revisão bibliográfica ou um artigo com uma estrutura frequente no mundo das revistas científicas que começa por colocar hipóteses, descrever metodologia e resultados e termina com as habituais observações finais. Em primeiro lugar o artigo debruça-se sobre a principal razão dos constrangimentos antigos (e actuais) à teoria evolutiva proposta por Darwin. Nos dias de hoje muitas das publicações de Charles Darwin continuam a ser marcos científicos e representam uma das maiores contribuições de sempre para a ciência. 
Apesar disso, devido a preconceitos e à ignorância, a teoria da evolução ainda luta para ser aceite em certos meios. Na primeira parte deste trabalho, Darwin é citado para ilustrar o seu pensamento e ideias visionárias e avançadas para o seu tempo sobre a origem e evolução dos primatas (humanos incluídos). Embora em pleno séc. XIX, carregado de influência Vitoriana, os pensamentos de Charles Darwin, sobre os outros primatas e, especialmente, sobre humanos, podem ser considerados livres de preconceitos. A segunda parte deste trabalho parte numa viagem ao passado, há milhares e milhares de anos, desde os ancestrais dos primatas até ao aparecimento dos primeiros primatas bípedes. Esta curtíssima (e resumida) viagem é apoiada não apenas em evidências vindas do registo fóssil mas também em informações vindas da Primatologia e da Etnografia. Finalmente, este trabalho termina com uma resumida descrição dos aspectos mais significativos do comportamento e da organização social dos chimpanzés enquanto modelo referencial para iluminar o processo evolutivo humano.

Palavras-chave Darwin; preconceitos; evolução; primatas; chimpanzés.

\section{Darwin, evolution and prejudice}

The bicentenary anniversary of the birth of Charles Robert Darwin (1809-1882) in 2009 faced some criticism from those who advocate intelligent design and other creationist pseudo-sciences.

Charles Darwin argued that evolution was driven by natural selection and that could explain the incredible variety of living organisms. Through natural selection, organisms most adapted to their environment would survive, reproduce and pass their advantages to their offspring. Such conclusions were reached by Darwin through a combination of meticulous observation and highly divergent and innovative thinking. In fact, with the theory of evolution, Darwin is responsible for one of the greatest contributions ever made to science (Dawkins, 2009). On the origin of species by means of natural selection, or the preservation of favoured races in the struggle for life (1859) along with other publications from this author [e.g. The Descent of Man, and selection in relation to sex (1871)] aroused world-wide controversy as blasphemous and atheistic works. Caricatures of the English naturalist displaying simian features were published in several magazines. Some constraints faced then by Darwin are still faced by scientists today (Dawkins, 2009). These come especially from the religious mainframe and are mainly based on prejudice. Waves of shock, as a consequence of the scientific revolutionary theory proposed by Darwin, still echo today. Many 
of these emanate from the prejudice of anthropocentrism, a specissist type of prejudice. Anthropocentrism perceives humans as the centre of all living organisms and as a superior being: such premise is the basis of most theories that emerged from the Christian-Judean philosophical and historical context. Humans are not only a superior being but they are also similar to God as it is not even conceivable that God may take a non human form. Such thinking is also embedded in another prejudice which is ethnocentrism (occidentalbased): from the Occidental point of view, God is never "black" or exhibits phenotypic features other than those present in a "white" individual. The anthropocentric prejudice is so strong that even most represented alien forms display humanoid features. Even amongst humans, some are special, chosen by God, and others are not: such way of thinking is an example of how attitudes towards "others" can be biased (Aiken, 2002; Yzerbyt and Leyens, 2004; Costa et al., 2010 submitted). Nazism created several categories of prisoners being Russian communists the lowest form of all (Arluke and Sanders, 1996; Serpell, 1996). Thus, prejudice regarding "others" ranks individuals (racism) or even other species (specissism/anthropocentrism) and it is the basis of racist and xenophobic behaviour towards "others".

Evolution is not directed towards specific goals or targets. It is accidental and does not exist because of humans or to make humankind: humans are a product of evolution such as all other living forms.

Darwin (1871: 197) saw humans as another primate form when he argued that: "No doubt man, in comparison with most of his allies, has undergone an extraordinary amount of modification, chiefly in consequence of his greatly developed brain and erect position; nevertheless we should bear in mind that he (man) is but one of several exceptional forms of primates". Furthermore, Darwin (1871: 186) stated that: "Some naturalists, from being deeply impressed with the mental and spiritual powers of man, have divided the whole organic world into three kingdoms, the Human, the Animal, and the Vegetable, thus giving to man a separated kingdom...... but he may endeavour to show, as I have done, that mental faculties of man and the lower animals do not differ in kind, although immensely in degree. A difference in degree, however great, does not justify us in placing man in a distinct kingdom, as will perhaps be best illustrated by comparing the mental powers of two insects, namely, a coccus or scale-insect and an ant, which undoubtedly belong to the same class". 
Humans are mammals and primates. Our species is included in the great ape group (Hominidae) with other species such as chimpanzees (Pan troglodytes), bonobos (Pan paniscus), gorillas (Gorilla gorilla) and orang-utans (Pongo pygmaeus). African great apes (chimpanzees, bonobos, gorillas and humans) are most similar to each other than to any other non human and among these, chimpanzees are closer to humans than they are, for example, to gorillas.

Although until almost the first half of the last century Asia was seen as the cradle of humankind, Darwin (1871: 197) had already argued that: "if the anthropomorphous apes be admitted to form a natural sub-group, then as man agrees with them, not only in all those characters which he possesses in common with the whole Catarhine groups, but in other peculiar characters, such as the absence of a tail and of callosities and in general appearance, we may infer that some ancient member of the anthropomorphous sub-group gave birth to man. It is not probable that a member of one of the other lower sub-groups should, through the law of analogous variation, have given rise to a man-like creature, resembling the higher anthropomorphous apes in so many respects".

While Darwin was alive, the religious, political, social and philosophical millieux were not favourable to bold statements such as those made by Charles Darwin, but he stated them anyway. No anthropocentrism can be found in the statement "the theory of expression confirms to a certain limited extent the conclusion that man is derived from some lower animal form" [Darwin, 1998 (1872): 360].

Evolution theory is an elegant and brilliant work, evidencing clear, robust and enlightening ideas.

\section{Primate evolution and extant primates}

\section{When primates arouse}

Primates probably appeared between 50-90 million years (MY) ago, during the end of the Cretaceous Period although the oldest known fossil primate dates to the 40-50 MY time range (Hartwig, 2007). One of the recent and provocative candidates to earliest fossil primate is a specific species of the Teilhardina genus (Old World omomyid) found in China and dated as having 55 MY (Ni et al., 2004). Ancient tarsier-like fossils discovered in 
China are other surprises that paleoprimatology has given scientist in the recent decade (Gunnel and Rose, 2002).

The environment along with geography (continental drift) changed through out the Cenozoic Era. During the Paleocene Epoch (55 to $65 \mathrm{MY}$ ), from the primatological point of view, some rodents had already a few interesting features [auditory canal anatomy and eventual grasping abilities (Hartwig, 2004)]. That was the case of some Pleasiadapiforms although the postorbital bar was missing as other primate features such as forward-facing orbits and generalized dentition (Hartwig, 2004; 2007). The tiny Carpolestes had prehensile feet with fingernails.

During the Eocenic Epoch (55 to $35 \mathrm{MY}$ ) climate was hot and humid and the first strepsirhine, haplorhine and anthropoid appear. Primates could be found in several continents, ranging from North America to Asia, Africa and Europe. Adapis, Europolemur or Notharctus were some of these primates. All three (Adapidae group) were diurnal, medium size primates. Adapids display a striking resemblance to extant Lemuridae. As for Omomyids, they ranged through out North America and Europe and were slightly smaller than Adapids (e.g. Tetonius) and resemble extant nocturnal primates such as Tarsius. Some Omomyids were leapers. Well-known anthropoids (Africa and Asia) such as Catopithecus browni (late Eocene Epoch) were medium/ small size, diurnal and frugivorous. Catopithecus displays a combination of primitive (unfused mandible) and advanced traits (full postorbital closure and two molars) that upset traditional divisions among early anthropoids (fused mandibles), platyrrhines (retention of three molars), and catarrhines (two premolars) (Hartwig, 2007: 15).

\section{From the Oligocene (Paleogene Period) to the Miocene (Neogene Period)}

During the Oligocene Epoch (35 to $23 \mathrm{MY}$ ), climate change coincided with the appearance of primates such as the first definitive catarrhines, platyrrhines, lemurs and loris. Propliopithecids (e.g. Aegyptopithecus) appear around the same Epoch displaying the catarrhine dental formula (2.1.2.3) and being also frugivorous, arboreal and average size primates (Conroy, 2004; Hartwig, 2004). Apidium moustafai and Apidium bowni date from that time. Latter, as climate got colder and drier, Parapithecids seemed well adapted to such environmental changes. These were average size frugivorous anthropoids (e.g. Parapithecus grangeri or Parapithecus 
fraasi). Other anthropoids were Qatrania fleagiei, Apidium phiomense and Propliopithecus chirobates. While Parapithecidae exhibited three premolars, Propliopithecidae displayed two.

During the Miocene Epoch (23 to $5 \mathrm{MY}$ ) just as other earlier primate species, some primates are also known only by their teeth and/or some parts of the skull (e.g. Mioeuoticus from Uganda and Komba from Kenya). Probably insectivorous and frugivorous respectively, Mioeuoticus and Komba were arboreal leapers of average size. As for Carlocebus or Homunculus (platyrrhine primates) they were found outside of the present platyrrhine geographical range and their relation with contemporary platyrrhines is unclear due to some unusual combination of traits (Conroy, 2004; Hartwig, 2004). Other Miocenic primates were Prohylobates and Victoriapithecus (probably medium size folivorous Cercopithecoids although only partially bilophodont). The crista obliqua was only absent in some of these (teeth such as molars and premolars displayed a reduced basal flare but hypoconulid features were lost in a few specimens). Latter platyrrhines such as Lagominico and Stirtonia were found but only in La Venta (Colombia) and displayed very diverse diets. La Venta fossils (16-12 MY) include many different platyrrhine taxa, bearing possible ancestors of Alouatta (Stirtonia), Aotus or owl monkeys (Aotus dindensis), Saimiri or squirrel monkey (Neosaimiri) and Pithecia [Cebupithecia (Hartwig, 2007)].

How primates got to South America is one of the most passionate questions of paleoprimatology. According to Hartwig (2007: 15) and assuming that anthropoids originated in the Old World, no scenario involving plate tectonics, rafting, vicariance biogeography, or island hopping is well supported. Maybe a miraculous transport via floating mats of vegetation is the only explanation, however fantastic it seems today. New World primate fossil record is very sparse. A few fossils are also known from Brazil, Bolivia, Chile, Colombia and Argentina being the earliest of all found in Bolivia and southern South America, dated to $26 \mathrm{MY}$ ago and not resembling any of the extant forms (Fleagle and Tejedor, 2002).

As the climate got colder and drier than in the earlier Miocene, macaques exhibited greater adaptative radiation. Mesopithecus is an example of a wellknown macaque. Although the fossil record is incomplete, several primate fossils were already well-known during Darwin's lifetime. That was the case of Miocenic great apes (along with modern platyrrhine families, colobines and cercopithecines) where several groups ranged through out Africa 
(Proconsulids), Europe (Dryopithecids) and Asia (Sivapithecids) beginning their dispersal around 15 MY ago (Hartwig, 2007). Most of Eurasian great apes were large body species (Klein and Edgar, 2002; Conroy, 2004; Hartwig, 2004; Stringer and Andrews, 2005). While some were arboreal, others were terrestrial. Some displayed suspensory features and of course, many similarities with the living great apes. Oreopithecus (from Italy) and Ouranopithecus (from Greece) are some well-known members of the Dryopithecid group. Sivapithecus (Asian Miocenic ape) is considered as the most probable ancestor of the contemporary orang-utan. But while in the beginning of the Miocenic, forests used to range until what is today known as United Kingdom, by the end of this period, the already mentioned climate change (as a consequence of continental drift) was responsible for the disappearance of numerous forest-like environments and with these, many ape-like primates. An explosion of macaque species (the macaque radiation) can then be acknowledged in the fossil record (Conroy, 2004; Hartwig, 2004; 2007; Boyd and Silk, 2009). Recent fossil descriptions of Dryopithecus and Oreopithecus have demonstrated that ape-like brachiation may date back to the first descendents of Pronconsul, especially Dryopithecus (Hartwig, 2004; 2007). Proconsul is a beautiful and remarkable landmark fossil as an early member of a radiation (just as Aegyptopithecus previously was). Morotopithecus (MacLatchy, 2004) is also seen as a hominoid; it was discovered not only outside Fayum (the most striking paleoprimatological site, located in Egypt), but also outside North Africa, in Uganda. Morotopithecus, Nacholapithecus and others remind us that any synthesis of early primate evolution is subject to quick and surprising changes and revisions.

\section{The first bipedal primates}

Between 4 to 6 million years ago (MY) the division of a single evolutionary line, where the ancestor of contemporary chimpanzees and humans was included, took place. Sahelanthropus tchadensis (TM 26601-060-1, nicknamed "Toumaii") discovered by M. Brunet and co-workers (2001) in Tchad (Toros-Menalla at the Djurab Desert) lived during this Epoch, between 7 and 6 MY. Toumaï is interesting also because it lived in a geographical region, far from what is known as the "hominine trail" (East Africa), in a mosaic habitat where savannah and open woodland were common. Sahelanthropus displayed a mixture of both derived and primitive features: a very modern face (reduced sub-nasal prognathism), bipedal behaviour (deducted also from the foramen magnum anterior position) but 
massive eyebrow ridges and primitive teeth. Toumaï individuals display important dental features such as small worn canines (apical wear), medium post canine enamel thickness and lacked the canine diastema (Hartwig, 2004). Sahelanthropus had a small brain size (ranging from 320 to $380 \mathrm{c}$. c.) and the shape of the basio-occipital area of a truncated triangle (skull similar to extant Gorilla). It is proposed as being close to hominine ape split, perhaps a sister group to later hominines. Wolpoff and co-workers (2002) proposed the inclusion of Toumaï in an alternative genus (Sahelpithecus), high-lightening primitive features.

Orrorin tugenensis lived between 6.2 and 5.6 MY and was discovered by Senut and Pickford (2000) in the Tugen Hills (Lukeino Formation in Kenya). When introduced to the scientific community in 2000, Orrorin was announced as the millennium man. He displays similarities with anatomically modern humans but also with extinct hominines [e.g. anterior ape-like dentition but small molars (similar to $A$. ramidus) and a deep and robust mandibular corpus as seen in early hominines]. The species also exhibits a set of features eventually related to locomotion: elongated femoral neck (but with asymmetric distribution of cortex although less asymmetrical than in known bipeds), presence of linea aspera (although more laterally placed than in other hominines), shallow superior notch, well developed gluteal tuberosity and presence of obturator externun groove [found in non bipeds (Hartwig, 2004)].

On the other hand, Ardipithecus ramidus (discovered in 1994 by T. White in Aramis, Middle Awash, Ethiopia) lived between 5.5 to 4.4 MY (transition period dating from the Miocenic to the Pliocenic Epoch) in a closed woodland habitat [tree covered habitat (Conroy, 2004; Stringer and Andrews, 2005)]. This species shares several features with other hominines such as small brain and small canines, but also exhibits some ape-like features (e.g. air pockets in the base of the skull). Ardipithecus canines are large such as chimpanzee canines although more incisiform (and the upper ones are broad) and projected. The canine wear pattern is more human-like. The cranial base is short and the foramen magnum is anteriorly placed. Some arboreal adaptations can still be seen in the forelimb remains (long powerfully muscled arms) but no knuckle walking features were found (Hartwig, 2004).

As for Ardipithecus kadabba (Middle Awash, Ethiopia), the species (Haile-Selassie et al., 2004) lived between 5.2 and 5.6 MY (earlier than A. ramidus), during the end of the Miocenic Epoch (Messinian Age). $A$. 
kadabba was smaller than his predecessor (A. ramidus) and displayed primitive morphology.

But in 1999, before the discovery of Australopithecus ramidus, another hominine was discovered: it was Kenyanthropus platyops which lived between 3 and 4 MY (Pliocenic Epoch). This species was found in the Lomekwi/ Turkana region (KNM-WT 40 000). With a very ape-like skull (small brain), Kenyanthropus displayed a very Paranthropus-like broad face (board flat face and small teeth) and was also a bipedal hominine (Hartwig, 2004).

\section{Plio-Pleistocene and the australopithecine clades}

The oldest australopithecine (Australopithecus anamensis) belongs to the gracile clade of the group (lived from 4.0 to 3.9 MY). It was first found in 1994 in two sites of the Lake Turkana: Allia Bay and Kanapoi. It displays both primitive (large stout canines, parallel tooth rows and thick mandible) and what may be considered derived features [thicker enamel, broader molars, derived humerus and expanded knee joint (Hartwig, 2004)]. As for Australopithecus bahrelghazeli, it was discovered in the nineties in Bahr el Ghazeli [Chad (Stringer and Andrews, 2005)]. This gracile australopithecine lived between 3.5 and $3 \mathrm{MY}$. The species exhibits similar teeth to the later Australopithecus afarensis although the enamel is thinner and teeth also bear different shapes. A. afarensis lived between 3.4 and 2.8 MY and was first found in 1974 in Hadar (Ethiopia) but several sites exist today (e.g. Awash River/Ethiopia and Laetoli/Tanzania). This species is probably the best well-known of all australopithecines: it is represented by many specimens of different ages, sexes and most skeleton parts. One of the most complete individuals ever discovered is Lucy (AL $288-1$ ). With this finding it became evident that bipedalism (short but bipedal hind limb) took place before brain expansion. A. afarensis had large front teeth, a prognathic face and a small brain (around 415 c. c.). Regarding post cranial remains it had long and powerful forelimbs. It was a highly sexually dimorphic species where males could be twice as large as females. Bipedal locomotion was strongly discussed in Lucy. This australopithecine exhibits valgus knees, a lumbar curve, a short curved pelvis but it also displayed a cone shaped torso, broad strongly muscled shoulders, and long arms and curved phalanges [arboreal-like features or climbing adaptations (Hartwig, 2004)]. Such trait combination pointed out to a bipedal hominine that still 
spent some time in the trees (Klein and Edgar, 2002; Stringer and Andrews, 2005). As for the Laetoli footprints (discovered by M. Leakey), these are definitely bipedal over a track of 27 meters. Footprint analysis showed short toes and a developed arch but also a slightly opposed hallux.

Another well know gracile australopithecine is Australopithecus africanus. The species lived between 3.0 and 2.4 MY and was found mainly in South Africa [e.g. Sterkfontein, Taung or Makapansgat (Bonner et al., 2007)]. The habitat occupied by $A$. africanus was characterized by the existence of clumps of woodland in open environment (e.g. savannas). Postcranial remains differ little from postcranial evidences from $A$. afarensis. The braincase (500 c. c.) was also similar but more domed. The face was deeper and less prognathic than in the A. afarensis case and there were differences in the dentition (e.g. smaller incisors and canines but larger molars) evidencing a shifting away from slicing (e.g. fruit) towards grinding and crushing (Hartwig, 2004). The first specimen to be found in1924 by Raymond Dart was a child (the Taung child) but it generated a fierce discussion (Bonner et al., 2007) regarding identity (e.g. chimpanzee, human, among other). The foramen magnum was forwardly placed, there were no brow ridges and the forehead was high. The Taung child had no projecting canines or gap between the lower canines and the premolars. Nevertheless, Dart was the target of fierce criticism and great scepticism as the cradle of the humankind then was though to be in Asia. The Piltdown skull fraud was an example of such though. But the Taung child, with a human-like jaw and an ape-like brain, pointed out Africa as the continent for the development of the humankind (Bonner et al., 2007). The dispute was only solved when an adult specimen (Mrs Ples/STS 5) was found. That happened in 1947 with Robert Broom. Dart's friend, Broom demonstrated that the Taung child was not an ape (Bonner et al., 2007). Discoveries of more specimens were made after that and sexual dimorphism became clear along with the importance of the species regarding the evolution of robust autralopithecines (Paranthropus). The major difference amongst both gracile and robust clades does not reflect any body size but dentition and changes associated in the skull morphology. All Paranthropus displayed adaptations for heavy chewing: marked sagital crests, massive jaws and huge crushing and grinding teeth which were chewing specializations to process high quantities of low quality food. They were found in both East and South Africa and probably represent a side-group regarding the lineage that eventually led to Homo sapiens. It is argued that they probably derived from the A. afarensis or A. africanus. They 
were bipedal hominines and lived in dry, seasonal and open environments (Klein and Edgar, 2002; Hartwig, 2004; Stringer and Andrews, 2005; Bonner et al., 2007; Klein, 2009).

The oldest member of the robust clade was Paranthropus aethiopicus. This robust australopithecine lived between 2.6 and 2.2 MY. Also known as the black skull (KNM-WT 17000) it is very well-known and was found in 1985 in the Lake Turkana region (Kenya). P. aethiopicus displayed small cranial capacity (400 c. c.), large cheek and front teeth, a highly marked sagital crest and a very pronounced prognathic face (Hartwig, 2004). In 1967 he was also found in Ethiopia (OMO 18) and was then named as Paraustralopithecus aethiopicus. This first finding was relatively ignored until the discovery of the beautiful black skull.

Australopithecus garhi (found in Bouri/Ethiopia in 1999) lived 2.5 MY ago. His cranial capacity reached around $450 \mathrm{c}$. c. and he displayed canine and premolar teeth similar to Homo species. Hug molars and a prognathic face are other observed features. The legs were very human-like although his arms displayed very ape-like resemblances (Hartwig, 2004). What is interesting in A. garhi were the tools found associated with the anthropological remains. Evidences of large mammal butchery were detected (Stringer and Andrews, 2005; Boyd and Silk, 2009).

Paranthropus boisei (OH5 or "Zinj", discovered by Mary and Louis Leakey and initially named Zinjanthropus boisei) is another robust hominine that was discovered in several sites in Ethiopia, Kenya and Tanzania. With a brain very similar to those of other robust australopithecines (500 c. c.) $A$. boisei had a flat, broad, concave and deep face with flaring zigomatic bones (cheek bones), a massive skull and massive cheek teeth (as in other robust forms) although the front teeth were small and "crowded" (Hartwig, 2004). The species lived between 2.3 and 1.2 MY. Also, as other australopithecines, the species was highly dimorphic.

Finally, within the robust clade the most recent member is Paranthropus robustus that lived between 2.1 and 1.2 MY. This australopithecine is limited to South Africa (Kroomdraai and Swartkrans). As other Paranthropus he had a face that was heavily built, massive cheek teeth (although not as large as Paranthropus boisei did) and he displayed small anterior teeth (Hartwig, 2004).

Around $1 \mathrm{MY}$ ago no robust australopithecines can be found in the fossil record. Such absence can be interpreted as evidence that the clade was extinct by then. Environmental changes may have led to this disappearance. 
Or perhaps robust australopithecines were too specialised and could not to compete with other animals (Klein and Edgar, 2002; Hartwig, 2004; Stringer and Andrews, 2005; Klein, 2009).

\section{Behaviour and inferences}

Most sites where many of the first hominines where found were dry and seasonal habitats (Conroy, 2004; Hartwig, 2004; Stringer and Andrews, 2005; Klein, 2009).

The transition of our ancestors from a more arboreal life to a more terrestrial one (savannahs and open woods) did not occur in a short-term period (Klein and Black, 2002; Conroy, 2004; Hartwig, 2004; Stringer and Andrews, 2005; Klein, 2009). Such transition implied several changes such as those in body size (increasing body size), the size of the social groups increased, there were diet shifts and adaptations, and there were changes in the social structure and organisation apart from other behavioural changes.

The first hominines had a terrestrial way of life, lived in multi-male/ multi-female social groups where a light form of sexual labour division could be found (as in chimpanzees) and where both sexes exploited slightly different diets (also as seen in chimpanzees).

Extant hunter-gatherers display sexual role division with men hunting big game and women hunting small mammals, gathering, preparing food and taking care of offspring (Lee and Daly, 1999; Panter-Brick et al., 2001). Meat is shared and individuals that do not shared are negatively perceived by other community members (Lee and Daly, 1999; Panter-Brick et al., 2001). Meat consumption allowed our ancestors to eat high quality food ("compact" chunks of proteins). Meat provides many calories and nutrients, it is transportable (from the hunting site to a central base camp) and it can be shared. Sharing is important: most of the times an individual hunts is not successful. But if the meat that was hunted by a specific individual is shared, then there will be some degree of success for all group members. Thus, wide meat sharing reduces food scarcity periods. Amongst hunter-gatherers while some gather food or hunt small mammals (mainly women), other (men) hunt big game if available (Lee and Daly, 1999; Panter-Brick et al., 2001). Such strategy seems highly probably amongst our ancestors as after joining the product of both activities, food scarcity periods would be less probable to occur, increasing the survival of our ancestors. Furthermore, meat is an important diet component special in 
energetic terms. In humans the percentage of meat eaten varies ranging from $5 \%$ to 35\% (Boyd and Silk, 2009). In chimpanzees (Gombe, Tanzania) meat constitutes 5\% of the diet (Wrangham, 1975) although in particular seasons it may account for more. Chimpanzees hunt other primates, wild pigs, small antelopes and duikers, among other animals. These African great apes hunt co-operatively (Boesch and Boesch-Achermann, 2000). Most of the times, the meat is also shared with other individuals. When looking at models such as those provided by the social carnivorous [lions (Panthera leo), hyenas (Crocuta crocuta), wild African dogs (Lycaon pictus) or wolfs (Canis lupus)], none is exclusively a scavenger or a hunter. That was probably the case of our ancestors (Stanford and Bunn, 2001). Opportunistic behaviour ranged from feeding on dead or decomposing preys to steal these from small size predators. In contemporary hunter-gathered groups, meat consumption is related to three fundamental features: i) existence of a central base camp, ii) extensive food sharing and iii) sexual role division (Lee and Daly, 1999; Panter-Brick et al., 2001). It is probable that such food sharing behaviour may have been in the origin of other co-operative behaviours.

Archaeological evidences tell us that the first hominines used tool. The oldest tools were found in Olduvai Gorge (Mode I, Olduwan tools). Other tools may have been used before but they were probably built of non fossilized materials [e.g. such as chimpanzee probes or sponges for example, or such as materials used by Homo erectus (there is a total absence of coupde-poings in Asia probably due to the existence of other material such as bamboo, which does not easily fossilizes)].

The social behaviour of these hominines is somewhat intriguing as few behavioural features get impregnated in the fossil record. Nevertheless, some trends can be displayed with the help of anthropological and archaeological fossil findings, primatology, alospecific phenomenology and sometimes even ethnography (McGrew, 1992; Vieira, 1995) and ethno-archaeology (Casanova, 2006). Such "auxiliary tools" allow us to reconstruct the past (Vieira, 1995; Casanova, 2006). Primatology, in particular, can help us to travel back in time by displaying the behaviour of non human primates such as those with whom we shared a relatively recent common ancestor (African great apes, especially chimpanzees). 
Table 1. Summary of the Geological Time Table ${ }^{1}$ with primates.

\begin{tabular}{|c|c|c|c|}
\hline ERA & System Period & Series Epoch & Primates \\
\hline \multirow{7}{*}{$\begin{array}{l}\text { Cenozoic } \\
\text { (Present to } 65.5 \\
\pm 0.3 \text { ) }\end{array}$} & \multirow[t]{2}{*}{$\begin{array}{l}\text { Quaternary } \\
\text { (Present to 2.588) }\end{array}$} & $\begin{array}{l}\text { Holocene } \\
\text { (Present to 0.0117) }\end{array}$ & \\
\hline & & $\begin{array}{l}\text { Pleistocene } \\
\text { (From } 0.0117 \text { to } \\
2.588 \text { ) }\end{array}$ & $\begin{array}{l}\text { - Paranthropus robustus } \\
\text { - Paranthropus boisei } \\
\text { - Australopithecus garhi } \\
\text { - Paranthropus aethiopicus }\end{array}$ \\
\hline & \multirow[t]{2}{*}{$\begin{array}{l}\text { Neogene } \\
\text { (From 2.588 to } \\
23.03)\end{array}$} & $\begin{array}{l}\text { Pliocene } \\
\text { (From 2.588 to } \\
5.332 \text { ) }\end{array}$ & $\begin{array}{l}\text { - Australopithecus garhi } \\
\text { - Paranthropus aethiopicus } \\
\text { - Australopithecus africanus } \\
\text { - Australopithecus afarensis } \\
\text { - Australopithecus bahrelghazeli } \\
\text { - Australopithecus anamensis } \\
\text { - Kenyanthropus platyops } \\
\text { - Ardipithecus ramidus }\end{array}$ \\
\hline & & $\begin{array}{l}\text { Miocene } \\
\text { (From } 5.332 \text { to } \\
23.03 \text { ) }\end{array}$ & $\begin{array}{l}\text { - Ardipithecus ramidus } \\
\text { - Ardipithecus kadabba } \\
\text { - Orrorin tugenensis } \\
\text { - Sahelanthropus tchadensis } \\
\text { - Ancient great apes: Proconsulids, Dryopithecids and Sivapithecids } \\
\text { - Modern platyrrhine families, colobines and cercopithecines } \\
\text { - Lagominico and Stirtonia (platyrrhines) } \\
\text { - Cercopithecoids (?) such as Prohylobates, Victoriapithecus } \\
\text { - Carlocebus, Homunculus } \\
\text { - Mioeuoticus, Komba }\end{array}$ \\
\hline & \multirow[t]{3}{*}{$\begin{array}{l}\text { Paleogene } \\
\text { (From 23.03 to } \\
65.5 \pm 0.3 \text { ) }\end{array}$} & $\begin{array}{l}\text { Oligocene } \\
\text { (From 23.03 to } \\
33.9 \pm 0.1 \text { ) }\end{array}$ & $\begin{array}{l}\text { - Parapithecids } \\
\text { - Propliopithecids } \\
\text { - Appearance of the first definitive catarrhines, platyrrhines, lemurs and loris. }\end{array}$ \\
\hline & & $\begin{array}{l}\text { Eocene } \\
\text { (From } 33.9 \pm 0.1 \text { to } \\
55.8 \pm 0.2)\end{array}$ & $\begin{array}{l}\text { - Adapidae group, } \\
\text { - Omomyids, } \\
\text { - First definitive strepsirhines, haplorhines and anthropoids } \\
\text { - Carpolestes } \\
\text { - Teilhardina }\end{array}$ \\
\hline & & $\begin{array}{l}\text { Paleocene } \\
\text { (From } 55.8 \pm 0.2 \text { to } \\
65.5 \pm 0.3 \text { ) } \\
\end{array}$ & - Pleasiadapiforms \\
\hline \multirow[t]{2}{*}{$\begin{array}{l}\text { Mesozoic } \\
\text { (From } 65.5 \pm 0.3 \\
\text { to } 251.0 \pm 0.4 \text { ) }\end{array}$} & \multirow[t]{2}{*}{$\begin{array}{l}\text { Cretaceous } \\
\text { (From } 65.5 \pm 0.3 \text { to } \\
145.5 \pm 4.0 \text { ) }\end{array}$} & $\begin{array}{l}\text { Upper } \\
\text { (From 65.5 } \pm 0.3 \text { to } \\
99.6 \pm 0.9 \text { ) }\end{array}$ & \\
\hline & & \begin{tabular}{|l} 
Lower \\
(From 99.6 \pm 0.9 to \\
$145.5 \pm 4.0$ )
\end{tabular} & \\
\hline
\end{tabular}

Note: time in MY (millions of years)

${ }^{1}$ Based on the 2009 International Stratigraphic Chart (International Commission on Stratigraphy: http://www.stratigraphy.org/upload/ISChart2009.pdf - viewed on the $11^{\text {th }}$ November 2010) 


\section{The Chimpanzee universe}

Chimpanzee living range spreads across central Africa, from East (Tanzania) to West (Guinea-Bissau and Senegal).

Several sites are running for several decades thus contributing to our enlightenment regarding the knowledge of this ape [Gombe and Mahale (Tanzania), Tai (Ivory Coast), Kibale and Budongo (Uganda) or Bossou (Guinea-Conakry)]. Other more recent sites are also contributing with knowledge although they are still very recent [Gashaka (Nigeria), Fongoli (Senegal), Cantanhez and Cufada (Guinea-Bissau) amongst others].

The variety of habitats used by chimpanzees is also diverse, occupying from primary rainforests to savannahs, mosaic habitats to disturbed forests.

The chimpanzee life cycle encloses several stages: infanthood, juvenile and adolescent stages, adulthood and senescence (Goodall, 1986; Nishida, 1990; Boesch and Boesch-Achermann, 2000).

Chimpanzees live in multi-male/multi-female communities that may include between twelve, up to hundred and fifty individuals. Males are the core of the community as communities are patrilineal. When reaching maturity, females migrate to other communities (males are the phylopatric gender). This African great ape lives under a fission-fusion pattern [as some contemporary humans such as some hunter-gatherers as the !Kung San from Kalahari (Lee and de Vore, 1976; Lee, 1979; Lee and Daly, 1999; Panter-Brick et al., 2001] where the community constantly splits itself into parties according to resource availability. Resource abundance allows for the formation of larger parties. Party composition varies throughout the day and includes two or more individuals. Parties may be lead by both male and females. Several party types can be found: feeding parties (larger), travelling parties, among other. Variation in party composition may be explained by the individuals involved and their personality, season of the year, nature of resources, demographic features (number of infants, juveniles and adults of both sexes), females exhibiting sexual swelling, presence of potential predators, among many other factors (Goodall, 1986; Nishida, 1990; Reynolds, 2005).

In a society where males are the philopatric gender the strongest bonds occur, naturally, amongst male-male dyads, although relationships among these are not always peaceful: fights over power and dominance are frequent and may have serious consequences (de Waal, 1983; Goodall, 1986; Nishida, 
1990; Boesch and Boesch-Achermann, 2000; Casanova, 2006; Sousa and Casanova, 2008; Casanova et al., 2008; Mitani et al., 2010). In chimpanzee communities social dominance hierarchies are not static and linear (de Waal 1996, Casanova et al., 2000; Casanova, 2003, Casanova et al., 2008). Hierarchies change throughout time, especially amongst males. Female hierarchies seem to be more stable (de Waal, 1983; Casanova, 2003). During stability periods less agonistic behaviour amongst individuals is observed. Usually each community member acknowledges its social role (to a particular social rank correspond specific rights and duties) and acts accordingly (de Waal, 1983; Boesch and Boesch-Achermann, 2000; Casanova, 2006). When social roles are clearly defined, expectations are created (Casanova, 2006). As long as such expectations are fulfilled, the community is hierarchically stable and balanced. Nevertheless it is frequent for males to get involved in endless fights over dominance and social status. In these fights individuals use (and discarded) each other as socio-political tools to reach specific goals (de Waal, 1983; Casanova et al., 2000; Casanova, 2003; Casanova et al., 2008). If one dyad exhibits signs of social strength and can, somehow, endangered the dominance of a third individual, then this individual may sabotage such dyadic relationship, not allowing its development (de Waal, 1983; Nishida, 1990). Males develop power and dominance strategies that may take up to several years (de Waal, 1983; Goodall, 1986; Nishida, 1990). The male social status and the dominance rank depend on his strategic/ social intelligence: his ability to form coalitions and alliances, his age, his ability to please others, to reach consensus, among other features (de Waal, 1983; 2009). Amongst females it is mainly age that can be decisive in the conquest over hierarchical rank [apart from the ability to have other female friends (de Waal, 1983)]. Conflicts are solved with the help of mediators or peacemakers (de Waal, 1989; 1996; 2009).

Males can be highly intolerant towards "strangers" (Goodall, 1986; Nishida, 1990; Wrangham and Peterson, 1997, Mitani et al. 2010). Chimpanzees are considered to be xenophobic and intolerant towards members of outside communities (Wrangham and Peterson, 1997; Mitani et al., 2010). Together, males may patrol community boarders in total silence, climbing up trees in an attempt to detect "foreigners". If detected, strangers may be immediately attacked (sometimes mortally), specially, when travelling alone. Infanticide was already observed in some chimpanzee communities and in different contexts (Goodall, 1986; Nishida, 1990; Wrangham and Peterson, 1997). 
Allogrooming behaviour has a central role in the life of chimpanzees. It is frequent to see several individuals grooming in a grooming chain that may take up to several hours (de Waal, 1983; Goodall, 1986; de Waal, 2009). Reciprocity is frequent during allogrooming episodes. Allogrooming behaviour usually occurs in relaxed and peaceful contexts and it is not always dependent on social status or gender (de Waal, 1989; 1996; 2009). It is especially strong amongst male-male and mother-offspring dyads. Nevertheless, it may also be very strong among non-related individuals (de Waal, 1989; 1996; Boesch and Boesch-Achermann, 2000; de Waal, 2009). But allogrooming episodes may also occur in anxious and tense contexts: a subordinate may be approached by a dominant individual to be groomed. If the subordinate is tense, the dominant individual may tranquilize him grooming, kissing and comforting him in order for the first to feel some reassurance (de Waal, 1989; 1996; 2009; Boesch and Boesch-Achermann, 2000). Therefore, allogroming may work as a tranquilizer. Chimpanzees may trade grooming per grooming, per support in future coalitions or even tolerance at feeding sites.

Chimpanzees are considered frugivorous (Goodall, 1986; Nishida, 1990; Boesch and Boesch-Achermann, 2000). Apart from fruits, which compose the majority of their diet, they also feed on leaves, flowers, seeds, nuts, tuberculae and other wart-like excrescences, bulbs, roots, shoots, honey, eggs, termites and other animals (gazelles, bush babies, birds, baboons, colobus monkeys, wild pigs), among other food items. These great apes hunt co-operatively and the hunting product can be shared (Boesch, 2005; Wrangham and Peterson, 1997). Since males hunt the most, they also ingest more proteins coming from the carcasses of the hunted preys (e.g. gazelle meat, wild pigs and other non human primates) than females do. On the other hand, proteins ingested by females come mainly from termites, ants and other insects (McGrew, 1992). Just as in other mammals, in most primates motherhood is a biological constraint that does not allow for females to abandon infants without putting these at risk (Campbell, 1999; Casanova, 2006; Boyd and Silk, 2009). Due to such constraint, females have to build more tools (to capture insects) than males (that can hunt as these do not have offspring directly under their care). Hence, there are slight sexual differences regarding activity types performed by both sexes (sexual role division, although incipient) and there are differences in the diet consumed by both male and females (McGrew 1992; Boyd and Silk, 2009) with the 
later using more extractive processing techniques (gathering and processing) and the former using more hunting techniques.

Anthropologists believe such role division based on gender was already present in the first hominines in a light way, but, it became stronger and more widespread throughout time (Conroy, 2004; Hartwig, 2004; Stringer and Andrews, 2005; Casanova, 2006; Boyd and Silk, 2009; Klein, 2009). Such chimpanzee feature (light sexual role differences) may be seen as the starting point for a role division based on gender that was latter consolidated amongst hominines [and it is also widely seen in many contemporary hunter-gatherers (Lee and Daly, 1999; Panter-Brick et al., 2001)], especially with males as hunters and females as gatherers. Such pattern does not imply that males can not gatherer food or that females can not hunt. In fact, females without offspring can be excellent hunters (Boesch and Boesch-Achermann, 2000) or even patrol along with males (Goodall, 1986; Casanova, 2003). Sexual role division was favoured by natural selection due to the reproductive physiology present in all mammals; such physiology dictates that parental investment is higher for females than for males (Campbell, 1999; Casanova, 2003).

Regarding tool use and tool building it is probable that such patterns, present in chimpanzees, were already present in hominines such as "Toumai" or Orrorin tugenensis (or maybe even in some Miocenic ape ancestors).

Apart from humans, chimpanzees display the largest set of cultural behaviours: "termite-fishing", "ant-dipping", "nut-cracking", "leafsponging", "pestle-pound", "hand-clasp grooming", "ant-wipe”, among many other behaviours.

Food sharing, along with tool use (and build), co-operative hunting and the light sexual role division previously mentioned are central features when considering African great apes (especially chimpanzees) as homologous models to explain the evolution of the human lineage. This does not equal to say that human ancestors were chimpanzees. But these two species do share a common ancestor. Anthropologists believe that behaviours currently shared by both humans and chimpanzees were already present in the common ancestor (Casanova, 2006). For example, the use of anvil and hammers to break oil palm nuts by chimpanzees is thoroughly documented and goes back until at least 4.000 years ago (Mercader et al., 2002).

Chimpanzees help us to develop ideas on the origins of human behaviour because they display a set of behavioural traits that are considered 
to be fundamental in human traditional societies [e.g. hunter-gatherers (Lee and Daly, 1999; Panter-Brick et al., 2001; Boyd and Silk, 2009)]:

a) Built tools from vegetable items and use of stone tools;

b) Hunt other mammals co-operatively;

c) Shared food, especially meat (a widely spread behaviour);

d) Displayed light sexual role differences;

By observing human and chimpanzee shared behaviour, anthropologists can build a past perspective of how the first hominines behaved (McGrew, 1992; Vieira, 1995; Stringer and Andrews, 2005; Boyd and Silk, 2009).

Since both human and chimpanzees display cultural behaviour, it is only natural to admit that the common ancestor of both species also exhibited this behavioural trait.

Culture used to be a forbidden concept when used in non human contexts. Nevertheless and due to the numerous published evidences (e.g. Whiten et al., 1999, Whiten and Boesch, 2001; Whiten et al., 2001; Whiten et al., 2003; Assersohn et al., 2004; Whiten, 2005; Whiten and van Schaik, 2007; Whiten et al., 2007; Whiten and Mesoudi, 2008; de Waal and Bonnie, 2009) such taboos no longer make sense. As McGrew (2004: 31) stated: "Anthropology invented the culture concept, but no longer owns $i t$ ". Nevertheless, anthropologists are reluctant to let non-anthropologists to jettison the culture concept (Ingold, 2001 in McGrew, 2004).

The concept of culture has been changing throughout the times, especially since the decade of 1960 with the discovery by Goodall of tool building behaviour in chimpanzees. Tool building used to be considered a feature that separated humans from other great apes and in that sense, the definition of culture was only applied to our own species as humans were the only ones that built tools (contrary to tool using that was known in many species). After the termite-fish tool description (and other discoveries that follow), the definition of culture was challenged in its anthropocentric dimension (Casanova, 2006). Several changes were then introduced in order to apply the concept only to humans: culture was, then, the ability to build tools to change or even perfectioning other tools. But in the decade of 1980 Matsuzawa discovered what the author labelled as meta tool (for further developments see for example: Matsuzawa, 1991; Sakura and Matsuzawa, 1991; Sugiyama et al., 1993; Matsuzawa, 1994; Inoue-Nakamura and Matsuzawa, 1997; Biro et al., 2003), which could be seen as a behavioural 
strategy to bring stability to the set hammer/anvil by adding a third element (to balance the anvil to prevent the nut from rolling over when cracked), thus, a perfectioning behaviour. Since then, numerous definitions of culture still keep an anthropocentric basis via several dimensions (e.g. specifically stressing the link between culture and cognition as the most determinant or clearly stating that culture is a behavioural strategy that only exists in humans). Definitions may also carry prejudice (Aiken, 2002; Yzerbyt and Leyens, 2004). It seems to be the case when efforts are made to keep a concept only applied to humans (specicism/anthropocentrim). In fact, science and scientists are not free from being influenced by prejudice.

Culture may be understood as a set of contents that is transmitted via learning and observation throughout generations until it becomes a feature shared by all members of the population or community. It may be seen as a set of knowledge, beliefs, art, moral, traditions and practices or any other abilities and habits acquired by an individual as a member of a group. Although such definition may be considered simple, it implies several features as follows: a) culture as an entity, b) culture as bearing contents and c) culture as something shared, socially (McGrew, 2004).

When considering such study object, anthropologists describe detailed analysis of all cultural features or components of a specific culture. McGrew (2004), inspired in Kroeber (1928) proposed a set of criteria to bear into consideration when deciding if a behaviour can, in fact, be considered as cultural. McGrew (2004) applied this analysis to chimpanzee behaviour and identified examples of all the criteria proposed initially by Kroeber (see Table 2).

Table 2. Criterion for cultural behaviours (adapted from McGrew 2004: 18).

\begin{tabular}{|l|l|l|l|}
\hline \multicolumn{1}{|c|}{ CRITERION } & \multicolumn{1}{|c|}{ CULTURAL FEATURE } & \multicolumn{1}{c|}{ EXAMPLE } & \multicolumn{1}{c|}{ REFERENCE } \\
\hline Innovation & New pattern (invention or modification) & Pestle pound & Yamakoshi and Sugiyama (1995) \\
\hline Dissemination & Pattern acquired from another individual & Social scratch & Nakamur and Uehara (2004) \\
\hline Standardization & $\begin{array}{l}\text { Pattern exhibited in a systematic and } \\
\text { consistent way }\end{array}$ & Ant dip & McGrew (1974) \\
\hline Durability & $\begin{array}{l}\text { Pattern seen even when others are not } \\
\text { present }\end{array}$ & Leaf sponge & Goodall (1986) \\
\hline Subsistence & Pattern transmitted throughout generations & Nut crack & Matsuzawa (2003) \\
\hline Diffusion & Patterns changed between groups & $\begin{array}{l}\text { Hand-clasp } \\
\text { grooming }\end{array}$ & Nakamura and Uehara (2004) \\
\hline
\end{tabular}


McGrew (2004) proposes a set of essentials or traits so that behaviours may be labelled as cultural:

i) Culture is learned: it is knowledge that is not genetically transmitted (although the capacity to display it is);

ii) Culture is socially learned: it is not solitarily acquired (albeit is through trial-error, insights; it is learned from other individuals within the community, it may imply observation of models, among other characteristics);

iii) Culture is normative: the expression of culture is not random but limited in time and space and

iv) Culture is social/shared: it is a group features (at community or nation level).

Regarding comparative analysis, when discussing culture definitions, behaviour has been the main focus as this can be observed, recorded, analysed; although as previously mentioned, culture is about cognition, mind and conception, even knowledge is not enough (McGrew, 2004).

Amongst non humans we can find several examples of "traditions" or well established cultural differences that are maintained through several social transmission mechanisms. Famous examples comprise the singing "dialects" in white-crowned sparrows (Zonotrichia leucophrys), the use of sponges by certain species of dolphins or even the sweet-potato washing amongst Japanese macaques (Macaca fuscata) at Koshima Island and the use of stones amongst capuchin monkeys (Moura and Lee, 2004). Chimpanzees also use stones (anvil and hammer) for nut cracking (for recent perspectives on tool use see Carvalho et al., 2008 or Carvalho et al., 2009) and many other non humans use tools to reach specific goals (vultures, sea otters, capuchin monkeys, gorillas, among others). However, each of these examples regards to a single variation within a unique behavioural type. In fact, using a tool is very different from building one. When building a tool, the individual modifies something that is available in order to reach a pre-defined target. Building implies the existence of a tool concept in the mind of the builder and the passage through a "chain of operations" (concept used also in ethnographic research) or stages where the object is transformed until it reaches its final stage. Building a tool with specific standard features (e.g. length, thickness) evidences that there is a pre-conceived idea of what is a tool (and its purpose). When building tools, chimpanzees are involved 
in an activity that prepares them to a spatial and temporal task performed elsewhere, involving some level of anticipation and planning (McGrew, 2004). This also means that there is a pre-conceived idea of what the tool is (and its purpose). Within the chimpanzee complex cognitive process associated to tool building, two or more tools may be used in a sequence in order to complete a single task. Furthermore, a tool may be used to build another tool; tools may be selected some time before they are really used; tools can be modified before being used and can be manipulated in different ways to solve new problems. Amongst great apes too the tool use and building are more complex than in any other non humans. Another approach (Whiten et al., 1999; Whiten and Boesch, 2001; Whiten et al., 2001; Whiten et al., 2003; Assersohn et al., 2004; Whiten, 2005; Whiten and van Schaik, 2007; Whiten and Mesoudi, 2008; Whiten et al., 2007; de Waal and Bonnie, 2009) enlightens diversity in cultural patterns (Whiten et al., 1999; 2001). Such assumptions imply new methodological approaches (e.g. ethnography) recognizing the importance of variation. According to such perspective, Whiten and co-authors $(1999 ; 2001)$ presented numerous behavioural patterns that are present in some (but not in other) communities. Patterns explained by ecological items were ruled out from the sample (Whiten et al., 1999). Numerous variations within such behavioural patterns were recorded and described (Whiten et al., 1999; 2001).

Other well known cultural behaviour is the use of medicinal plants which is transmitted from generation to generation and varies from one community to another. Chimpanzees in Guinea-Bissau use the same plants that humans do to cure specific pathologies (Casanova and Sousa, personal information, 2007). This knowledge, information and traditions are not explained by genetics but instead, have to be learned. Cultural behaviours and traditions do not always have to be adaptative (McGrew, 2004). That is the case of handclasp grooming, a behaviour displayed according to the traditions that are operant in each chimpanzee community. While in one community during grooming episodes individuals cross their writs, in another hands are clasped (McGrew, 2004).

By studying species that share with us a common ancestor, insights may be taken regarding what made us humans and the evolutionary processes that shaped us. When and why culture became determinant may help us to explain the human trail and how we evolved. It is only possible to fully understand the present when it is understood the way that same present 
was reached. Methodologically speaking, studying humans outside an evolutionary context and an evolutionary tempo allows for an incomplete view of the humankind. Fossils are the only direct record of primate ancestry although these are fragmentary and difficult to interpreter. Also, the fossil record has intractable limitations (Hartwig, 2007: 13).

Extant African great apes are what remain of millions of years of competition with African cercopithecoids. While gorillas represent a more deep forest specialized herbivorous form, chimpanzees represent a moderated body size frugivorous form.

Much is to be learned from non human great apes but time is scarce regarding the conservation status of many non human primate taxa (Strier, 2007). Efforts to protect and conserve endangered non human primate species (e.g. GRASP) should be less timid and humans, more than any other species, have heavy responsibilities in the process.

"If we, in our travels in space, should encounter a creature that shares $98 \%$ of our genetic makeup, think of the money we would spend to study this species. Such creatures exit on earth and we are allowing them to become extinct."

(In: McGrew, 1992: 215).

\section{Bibliographic references}

Aiken, L. R. 2002. Attitudes and related psychosocial constructs: theories, assessment and research. Thousand Oaks, CA, Sage Publications.

Arluke, A.; Sanders, C. 1996. Regarding animals. Philadelphia, Temple University Press.

Assersohn, C; Whiten, A.; Kiwede, Z. T.; Tinka, J.; Karamagi, J. 2004. Use of leaves to inspect ectoparasites in wild chimpanzees: a third cultural variant? Primates, 45(4): 255-258.

Biro, D.; Inoue-Nakamura, N.; Tonooka, R.; Yamakoshi, G.; Sousa, C.; Matsuzawa, T. 2003. Cultural innovation and transmission of tool use in wild chimpanzees: evidence from field experiments. Animal Cognition, 6(4): 213-223.

Boesch, C. 2005. Joint cooperative hunting among wild chimpanzees: taking natural observations seriously. Behavioral and Brain Sciences, 28(5): 692-3. 
Boesch, C.; Boesch-Achermann, H. 2000. The chimpanzees of the Tai Forest: behavioural ecology and evolution. Oxford, Oxford University Press.

Bonner, P.; Esterhuysen, A.; Jenkins, T. 2007. A search for origins. Science, history and South Africa's "Cradle of Humankind”. Cape Town, Wits University Press.

Boyd, R.; Silk, J. 2009. How humans evolved. New York, W.W. Norton \& Company, Inc.

Campbell, A. 1999. Staying alive: evolution, culture and women's intrasexual aggression. Behavioural and Brain Sciences, 22(2): 203-252.

Carvalho, S.; Cunha, E., Sousa, C.; Matsuzawa, T. 2008. Chaînes opératoires and resource exploitation strategies in chimpanzee nut-cracking (Pan troglodytes). Journal of Human Evolution, 55: 148-163.

Carvalho, S.; Biro, D; McGrew, W.; Matsuzawa, T. 2009. Tool-composite use and reuse in wild chimpanzees (Pan troglodytes): archaeologically invisible steps in the technological evolution of early hominins? Animal Cognition, 12, S103-S114.

Casanova, C. 2003. Status and friendship in captive female chimpanzees (Pan troglodytes). Doctoral Dissertation. University of Cambridge, UK (Darwin Colllege and Department of Biological Anthropology).

Casanova, C. 2006. Introdução à Antropologia biológica: genética, princípios evolutivos e primatologia. Lisboa, Instituto Superior de Ciências Sociais e Políticas e Fundação para a Ciência e Tecnologia.

Casanova, C; Sousa, C. 2007. Personal information.

Casanova, C; Vicente, L.; Vieira, A. 2000. Remarks regarding the origins of politics: the community of chimpanzees (Pan troglodytes) as a referential model. Journal of Philosophy of Life Sciences, 7(13): 93-124.

Casanova, C.; Mondragon-Ceballos, R.; Lee, P. C. 2008. Innovative social behavior in chimpanzees (Pan troglodytes). American Journal of Primatology, 70(1): 54-61.

Conroy, G. C. 2004. Reconstructing human origins. A modern synthesis. New York, W. W. Norton \& Company, Inc.

Costa, S.; Casanova, C.; Sousa, C.; Lee, P. C. Submitted (2010). The good, the bad and the ugly: perceptions of wildlife in Tombali (Guinea-Bissau, West Africa). Environmental Psychology.

Darwin, C. R. 1859. On the origin of species by means of natural selection, or the preservation of favoured races in the struggle for life. London, John Murray.

Darwin, C. R. 1871. The descent of man, and selection in relation to sex. London, John Murray (Vol. I and II). 
Darwin, C. R. 1998 [1872]. The Expression of the emotions in man and animals. London, Penguin Classics.

Dawkins, R. 2009. The greatest show on earth: the evidence for evolution. New York, Free Press.

de Waal, F. B. M. 1983. Chimpanzee politics. Power and sex among apes. New York, Harper and Row.

de Waal, F. B. M. 1989. Peacemaking among primates. Cambridge, Harvard University Press.

de Waal, F. B. M. 1996. Good natured: the origins of right and wrong in humans and other animals. Cambridge, Harvard University Press.

de Waal, F. B. M. 2009. The age of empathy: nature's lessons for a kinder society. New York, Harmony Books.

de Waal, F. B. M.; Bonnie, K. E. 2009. In tune with others: the social side of primate culture. In: Laland, K. and G. Galef (eds.) The question of animal culture. Cambridge, MA, Harvard University Press: 19-39.

Fleagle, J. G.; Tejedor, M. F. 2002. Early platyrrhines of southern America. In: Hartwig, W. C. (ed). The primate fossil record. Cambridge, Cambridge University Press: 161-174.

Goodall, J. 1986. The chimpanzees of Gombe. Patterns of behaviour. The Belknapp Press of Harvard University.

Gunnel, G. F.; Rose, K. D. 2002. Tarsiiformes: evolutionary history and adaptation. In: Hartwig, W. C. (ed.) The primate fossil record. Cambridge, Cambridge University Press: 45-82.

Haile-Selassie, Y.; Suwa, G.; White, T. D. 2004. Late Miocene teeth from Middle Awash, Ethiopia, and early hominid dental evolution. Science, 303(5663): 1503-1505.

Hartwig, W. C. 2004. The primate fossil record. Cambridge, Cambridge University Press.

Hartwig, W. C. 2007. Primate evolution. In: Campbell, C. J.; Fuentes, A.; MacKinnon, K. C.; Panger, M.; Bearder, S. K. (eds.) Primates in Perspective. Oxford, Oxford University Press: 11-22.

Ingold, T. 2001. The use and abuse of ethnography. Behavioural and Brain Sciences, 24: 337.

Inoue-Nakamura, N.; Matsuzawa, T. 1997. Development of stone tool-use by wild chimpanzees (Pan troglodytes). Journal of Comparative Psychology, 111(2): 159-173. 
Klein, R. G. 2009. The human career. Human biological and cultural origins. Chicago, Chicago University Press.

Klein, R. G.; Edgar, B. 2002. The dawn of human culture. New York, John Wiley \& Sons Inc.

Kroeber, A. L. 1928. Sub-human culture beginnings. Quarterly Review of Biology, 3: $325-42$.

Lee, R. B. 1979. The !Kung San: men, women, and work, in a foraging society. Cambridge, MA, Harvard University Press.

Lee, R. B.; DeVore, I. 1976. Kalahari hunter-gatherers. London, Harvard University Press.

Lee, R. L.; Daly, R. 1999. The Cambridge encyclopedia of hunters and gatherers. Cambridge, Cambridge University Press.

MacLatchy, L. 2004. The oldest ape. Evolutionary Anthropology, 13: 90-103.

Matsuzawa, T. 1991. Nesting cups and meta-tool in chimpanzees. Behavioral and Brain Sciences, 14(4): 570-571.

Matsuzawa, T. 1994. Field experiments on use of stone tools by chimpanzees in the wild. In: Wrangham, R.; McGrew, W.; de Waal, F.; Heltne, P. (eds.) Chimpanzee cultures. Cambridge, Mass., Harvard Univ. Press: 351-370.

McGrew, W. C. 1992. Chimpanzee material culture. Cambridge, Cambridge University Press.

McGrew, W. C. 2004. The cultured chimpanzee: reflections on cultural primatology. Cambridge, Cambridge University Press.

Ni, X.; Wang, Y.; Hu, Y.; Li, C. 2004. A euprimate skull from the early Eocene of China. Nature, 427: 65-68.

Mercader, J.; Panger, M.; Boesch, C. 2002. Excavation of a chimpanzee stone tool site in the African rainforest. Science, 296: 1452-1455.

Mitani, J. C.; Watts, D. P.; Amsler, S. J. 2010. Lethal intergroup aggression leads to territorial expansion in wild chimpanzees. Current Biology, 20(10): R507-8.

Moura, A. C. de; Lee, P. C. 2004. Capuchin stone tool use in Caatinga dry forest. Science, 306(5703): 1909.

Nishida, T. 1990. The chimpanzees of the Mahale mountain: sexual and life history strategies. Tokyo, University of Tokyo Press.

Panter-Brick, C.; Layton, R. H.; Rowley-Conwy, P. (eds.) 2001. Hunter-Gatherers. An interdisciplinary approach. Cambridge, Cambridge University Press.

Reynolds, V. 2005. The chimpanzees of the Budongo forest. Ecology, behaviour and conservation. Oxford, Oxford University Press. 
Sakura, O.; Matsuzawa, T. 1991. Flexibility of wild chimpanzee nut-cracking behavior using stone hammers and anvils: an experimental analysis. Ethology, 87: $237-248$.

Serpell, J. 1996. In the company of animals - a study of human-animal relationships. Cambridge, Cambridge University Press.

Sousa, C.; Casanova, C. 2008. Are Great Apes aggressive? A cross-species comparison, Antropologia Portuguesa, 22/23: 71-118.

Stanford, C.; Bunn, H. T. (eds.) 2001. Meat-eating and human evolution. Oxford, Oxford University Press.

Strier, K. B. 2007. Conservation. In: Campbell, C. J.; Fuentes, A.; MacKinnon, K. C.; Panger, M.; Bearder, S. K. (eds.). Primates in Perspective. Oxford, Oxford University Press: 496-509.

Stringer, C.; Andrews, P. 2005. The complete world of human evolution. London, Thames \& Hudson.

Sugiyama, Y.; Fushimi, T.; Sakura, O.; Matsuzawa, T. 1993. Hand preference and tool use in wild chimpanzees. Primates, 34(2): 151-159.

Vieira, A. B. 1995. Ensaios sobre a evolução do homem e da linguagem. Lisboa, Fim de Século Edições.

Whiten, A. 2005. The second inheritance system of chimpanzees and humans. Nature, 437(7055): 52-55.

Whiten, A.; Goodall, J.; McGrew, W. C.; Nishida, T.; Reynolds, V.; Sugiyama, Y.; Tutin, C. E. G.; Wrangham, R. W.; Boesch, C. 1999. Cultures in chimpanzees. Nature, 399(6737): 682-685.

Whiten, A; Goodall, J.; McGrew, W. C.; Nishida, T.; Reynolds, V.; Sugiyama, Y.; Tutin, C. E. G.; Wrangham, R. W.; Boesch, C. 2001. Charting cultural variation in chimpanzees. Behaviour, 138: 1489-1525.

Whiten, A.; Boesch, C. 2001. The cultures of chimpanzees. Scientific American, 284: 48-55.

Whiten, A.; Horner, V.; Marshall-Pescini, S. 2003. Cultural panthropology. Evolutionary Psychology, 12: 92-105.

Whiten, A.; Horner, V.; de Waal, F. B. M. 2005. Conformity to cultural norms of tool use in chimpanzees. Nature, 437(7059): 737-40.

Whiten, A.; van Schaik, C. P. 2007. The evolution of animal 'cultures' and social intelligence. Philosophical Transactions of the Royal Society of London Series B; 362(1480): 603-620. 
Whiten, A.; Spiteri, A.; Horner, V.; Bonnie, K. E.; Lambeth, S. P.; Schapiro, S. J.; de Waal, F. B. M. 2007. Transmission of multiple traditions within and between chimpanzee groups. Current Biology, 17: 1038-1043.

Whiten, A.; Mesoudi, A. 2008. Establishing an experimental science of culture: animal social diffusion experiments. Philosophical Transactions of the Royal Society of London Series B, 363: 3477-3488.

Wolpoff, M. H.; Senut, B.; Pickford, M.; Hawks, J. 2002. Palaeoanthropology (communication arising): Sahelanthropus or 'Sahelpithecus'? Nature, 419(6907): 581-2.

Wrangham, R. W. 1975. Behavioural ecology of chimpanzees in Gombe National Park, Tanzania. Doctoral dissertation, University of Cambridge (Department of Zoology).

Wrangham, R. W.; Peterson, D. 1997. Demonic males: apes and the origins of human violence. New York, Houghton Mifflin Company.

Yzerbyt, V.; Leyens, J. P. 2004. Psicologia social. Lisboa, Edições 70.

Artigo recebido a 23 de Agosto de 2010 e aceite a 22 de Novembro de 2010. 